\title{
A Democracia pelo P/MDB: Estudo Crítico da Trajetória P/Emedebista na Transição Democrática (1974-1989)
}

\section{Introdução}

Há mais de 50 anos o Partido do/Movimento Democrático Brasileiro' vem se configurando como uma das partes fundamentais do sistema político institucional brasileiro. Do seu início em meio aos arbítrios da ditadura burgo-militar ${ }^{2}$ instalada no Brasil em 1964 até os dias atuais esta agremiação política é comumente caracterizada pela grande heterogeneidade de seus quadros e difícil definição doutrinária. O P/MDB ganhou também infâmia após o início da década de 1990, por ter participado enquanto base de sustentação (em algum momento) a todos os governos federais desde a Presidência de José Sarney (1985-1990).

1 Preferiu-se utilizar a grafia P/MDB por esta garantir a compreensão de que, dentro do recorte aqui utilizado (1974-1981), houve dois partidos diferentes institucionalmente inscritos e reconhecidos (MDB e PMDB). Contudo, ao uni-los em uma só grafia, garante-se entendê-los como componentes de um mesmo bloco político que, em diferentes momentos, uniu forças políticas afins e com o mesmo propósito: contrastar com o partido oficial dos governos militares (Arena e, posteriormente, PDS).

2 Utiliza-se aqui o conceito ditadura burgo-militar pautado principalmente pela concepção de José Milton Pinheiro de Souza (2014) e enquanto evolução da concepção de René Armand Dreifuss (2008). Preferimos essa forma em detrimento de outras concepções e tipologias utilizadas para qualificar o período de 1964 a 1985 justamente por deixar explícita a articulação de classe específica que organizou e realizou o Golpe de 1964, bem como conduziu o poder de Estado (com suas contradições internas e percalços conjunturais) ao longo deste período. Ele compreende uma classe ampla cuja contemplação dos interesses comuns a seus membros estava no centro do programa golpista, e uma corporação que assumiu a linha de frente da condução golpista e imprimiu ao Estado o seu programa político-econômico em consonância (e, casualmente, contradição) com o das diversas camadas da classe burguesa brasileira.

Prof. Me. Pedro Henrique

Gomes de Queiroz

Mestrando do Programa de Estudos Pós-Graduados em História da Pontifícia Universidade Católica de São Paulo (PUC-SP),

E-mail: pedroh. gomesqueiroz@gmail.com. 
Para além do senso comum encontram-se poucas análises mais aprofundadas sobre o $\mathrm{P} / \mathrm{MDB}$, especificamente no recorte aqui compreendido (1974-1985), focando no âmbito nacional. Muito já se estudou a atuação do MDB nas regionalidades e suas disputas eleitorais com a Arena, porém, pouco se tem escrito, especialmente no campo dos estudos históricos, sobre sua atuação em nível federal e as diferentes táticas de ação e articulações conjunturais tomadas por suas lideranças. Ademais, poucos estudos focam na formulação estratégica do partido, confrontando-a com seu funcionamento e as ações concretas tomadas enquanto oposição/governo.

Por isso a pesquisa aqui apresentada visa perscrutar a trajetória desta agremiação política focando no período da transição democrática (1974-1989). Tal período é essencial para compreendermos não só o partido, mas o funcionamento da política brasileira como um todo. Permeado por intensas mobilizações da classe trabalhadora em luta por seus direitos políticos e humanos, este foi um período de intensas transformações em termos de participação popular na política institucional, organização classista e rearticulação da burguesia nacional em torno do seu controle sobre o sistema político-econômico.

Para o P/MDB a transição representou um momento riquíssimo em seu desenvolvimento, uma vez que foi quando conseguiu chegar ao centro do poder de Estado, sofrendo forte reformulacão de seus quadros e da sua posição dentro do sistema político institucional. De coadjuvante subjugado passou a estar no centro das tomadas de decisão, colocando à prova o seu programa e lidando diretamente com as contradições da longa transição democrática brasileira.

Buscou-se, deste modo, compreender a articulação dessa grande agremiação partidária no contexto da transição democrática, bem como, a partir disto, as suas formulações sobre a democracia ${ }^{3}$. Diretamente relacionado a isso

3 Dada a multiplicidade gigantesca de compreensões sobre o termo democracia e a extensão das discussões sobre sua caracterização, impossiveis de se lidar com competência e abrangência necessárias neste espaço, esteve o intuito de mapear o funcionamento do P/MDB e das tentativas de conferir ação política coesa/unificada a seus membros, a capacidade de o partido representar a oposição à ditadura burgo-militar e seu papel central no processo de parlamentarização ${ }^{4}$ do conflito social brasileiro - e da própria luta de classes.

Para alcancar este feito foram analisados documentos internamente produzidos pelo P/MDB através de seu braço de produção intelectual e discussão interna (Fundação Pedroso Horta) ao longo da transição, tais como o Programa, Estatuto e Código de Ética do partido; a cartilha MDB em Ação (1972-1978), voltada para a militância e suas bancadas parlamentares; os especiais MDB no Rádio e na Televisão (1977) e Constituinte com Anistia (1978); a Revista do PMDB (1981-1988), meio interno de divulgação das discussões políticas realizadas por seus membros. Além de darem conta de todo o recorte escolhido, essas produções são importantes meios de averiguação das disputas internas do partido e da correlação de forças internas. São documentos que nos fornecem bons indícios sobre como um partido tão grande e diverso como o P/MDB pôde produzir um discurso coeso e um programa minimamente unificado (assim como o que levou a isto não ocorrer em determinados momentos).

E para pensar no essencial âmbito de difusão desse discurso, foi analisado um dos meios de comunicação mais relevantes, no Brasil, deste

deixaremos de lado o debate teórico sobre a mesma e focaremos na compreensão empírica dele produzida a partir das leituras de fontes do próprio P/MDB.

4 Definimos enquanto processo de "parlamentarização" dos conflitos políticos aquele através do qual o establishment político-econômico busca consubstanciar os protestos populares, as demandas de classe e disputas por poder no seio do Congresso Nacional, onde estes poderiam ser controlados "dentro das regras do jogo", subtraindo-se seus elementos de radicalidade e crítica à ordem socioeconômica. Buscamos aqui, assim, ver as duas pontas de um processo, no qual o partido está inserido, de estabelecer um relacionamento com a sociedade civil e ao mesmo tempo apartá-la sempre que possível das "grandes decisões" sobre seu futuro, tensão essa que é o ponto nevrálgico da participação popular na transição democrática. Essa discussão pode ser vista em Napolitano (2006). 
recorte: a Revista Veja. Já em meados da década de 1970 esse periódico conquistou a liderança das bancas de jornal do País em número de tiragens, chegando, em 1981, a uma média de 500 mil impressões semanais (com certas edições, como a do Comício da Sé das Diretas Já!, contando com 1 milhão de tiragens) $)^{5}$. Sua importância, portanto, é inegável para pensarmos a arena pública de debate político e social no País. Portanto, se é objetivo averiguar não apenas a produção do discurso sobre a democracia pelo $\mathrm{P} / \mathrm{MDB}$, mas também sua veiculação à população, este meio de comunicação pode fornecer interessantes contribuições à lógica de funcionamento da ação discursiva p/emedebista.

De forma a dar conta do universo de documentos disponíveis e das contradições inertes à ação p/emedebista, o método de estudo básico utilizado aqui é a análise de discurso, especialmente a de aporte bakhtiniano (BAKHTIN, 2016), com auxílio da análise crítica de discurso (FAIRCLOUGH, 2012; RAMALHO; RESENDE, 2011). Particularmente a concepção dialógica da comunicação do linguista soviético Mikhail Bakhtin (2016) nos permite compreender um P/MDB imerso dentro de um sistema político e contexto social que impactam diretamente sua formulação discursiva e, portanto, sua formulação teórico-estratégica (como ver-se-á à frente). Confrontando essa concepção discursiva com as produções intrapartidárias é possivel notar uma série de termos diretamente relacionados aos gêneros discursivos dos grupos de interesse em combate durante o período da transição, dos quais o P/MDB avidamente buscou ganhar apoio.

A visão crítica do linguista britânico Norman Fairclough (2012) é bastante complementar, dentro dos propósitos desta pesquisa, à de Bakhtin (2016), uma vez que ambos compreendem o discurso como um dado concreto da vida social, e não apenas uma abstração subjetiva. $O$ discurso molda, conduz e faz refletir sobre a ação do indivíduo, constantemente colocando-a em relação

5 CPDOC-FGV. Veja. FGV, 2009. Disponível em: <http://bit.ly/2p9wrCN>. Acesso em: 27 jul. 2018. aos seus pares na sociedade. Justamente por isso ambos compreendem o discursivo como uma prática, razão pela qual os discursos são um dado orgânico do fazer social, possibilitando perceber as mudanças, rearticulações, avanços e recuos no desenvolvimento do partido. Fairclough (2012) auxilia esta análise ao conferir relevância às relações de poder inscritas no discurso, particularmente para aquelas de dominância e hegemonia (através das quais um discurso domina a arena pública e de debate e torna os demais marginais, quando não subversivos). Em conjunto, essas visões nos possibilitaram ter uma percepção clara das contradições do recorte escolhido e do desenvolvimento do objeto.

\section{Criação, Institucionalização e Crise}

A história do P/MDB começou formalmente em 1965, com a outorga do Ato Institucional n. ${ }^{\circ}$, pelo general Humberto de Alencar Castelo Branco. Dentre as muitas peculiaridades da ditadura burgo-militar brasileira esteve um forte intuito desde seu princípio em justificar-se enquanto legal e democrática, como pode ser visto logo no Ato Institucional $n .{ }^{\circ} 7^{6}$. Dentro do pacote que formaria um simulacro democrático, isto é, a manutenção de instituições e ritos de uma democracia liberal formal (KINZO, 1988, p. 16-17) desvirtuados de forma a atenderem ao novo bloco no poder, estariam a rotação de presidentes, funcionamento do Congresso Nacional e legislativos locais, eleições periódicas e manutenção dos Três Poderes - porém, sempre manipulados de

6 "A revolução vitoriosa se investe no exercício do Poder Constituinte. Este se manifesta pela eleição popular ou pela revolução. Esta é a forma mais expressiva e mais radical do Poder Constituinte. Assim, a revolução vitoriosa, como o Poder Constituinte, se legitima por si mesma. Ela destitui o governo anterior e tem a capacidade de constituir o novo governo. Nela se contém a forma normativa, inerente ao Poder Constituinte. Ela edita normas jurídicas sem que nisto seja limitada pela normatividade anterior à sua vitória". (PRESIDÊNCIA DA REPÚBLICA. Ato Institucional n. ${ }^{\circ}$, de 9 de abril de 1964. Planalto, [1964]. Disponível em: <http://bit.ly/33XAJM9>. Acesso em: 1 jul. 2019). 
forma a impedirem contestações ao regime e à ordem socioeconômica.

A manutenção do funcionamento dos partidos vigentes no período pré-1964 foi um dos pilares iniciais desse simulacro. PTB, PSD, UDN7 e demais foram todos mantidos, e o governo de Castelo Branco buscou formar com esses uma base parlamentar forte que diminuísse as críticas ao arbítrio do governo e evitasse a necessidade de remodelação do âmbito parlamentar (ou mesmo sua extinção/supressão). UDN, PSP e parte do PSD foram logo para a base do governo, porém, formaram um grupo muito fracamente organizado e com disputas internas quase irreconciliáveis (KINZO, 1988, p. 24-27), especialmente após a não realização das eleições presidenciais em 1965. Além do mais, a sombra da poderosa aliança PTB-PSD era um medo constante para a ditadura, levando-a a extinguir os partidos e reformular a legislação partidária no Ato Institucional n. ${ }^{\circ}$ 2, $^{8}$ em outubro de 1965.

Esse ato objetivou garantir uma base parlamentar sólida e sustentável à ditadura no Congresso, porém, sem necessitar recorrer a um regime de partido único. A nova legislação partidária era tão restritiva que permitiu a formação de apenas dois novos partidos: Aliança Renovadora Nacional (Arena), de sustentação ao governo, e o Movimento Democrático Brasileiro (MDB), de oposição formal. Ainda que

7 PTB: Partido Trabalhista Brasileiro: criado por Getúlio Vargas, em 1945, para dar sustentação ao varguismo e congregar as forças sindicalistas e populares ligadas ao ex-presidente e seu projeto político-econômico. Foram membros o próprio Vargas, João Goulart e Leonel Brizola.

PSD: Partido Social Democrático: criado por intermédio de Getúlio Vargas, em 1945, para reunir os seus antigos interventores federais e líderes políticos regionais que dariam sustentação ao varguismo, porém, mais posicionados ao centro da política brasileira. Possuiu figuras como os presidentes Eurico Gaspar Dutra e Juscelino Kubitschek, Tancredo Neves, Ulysses Guimarães e Armando Falcão.

UDN: União Democrática Nacional: partido de oposição ao varguismo, com linha conservadora e defesa veemente das teses liberais clássicas. Foi coordenado majoritariamente por Carlos Lacerda.

8 PRESIDÊNCIA DA REPÚBLICA. Ato Institucional n. ${ }^{\circ} 2$, de 27 de outubro de 1965. Planalto, [1965]. Disponível em: <http://bit.ly/2Ncpadc>. Acesso em: 1 jul. 2019. formado com grande dificuldade (e, em parte, com auxílio do próprio governo ditatorial), o MDB conseguiu congregar em si boa parte das forças de oposição à ditadura que estavam colocadas na institucionalidade do poder.

Motta (1997, p. 32) define que boa parte da estrutura do MDB adveio justamente do antigo PTB, que adentrou quase em cheio ao novo partido. O MDB seria, assim, quase que um continuador do PTB e de sua forte aliança com o PSD, uma vez que herdou do partido varguista boa parte de sua estrutura física e parlamentares. Essa herança teria sido vital, segundo esse teórico, na consolidação do MDB e no seu processo de institucionalização na nova conjuntura política nacional. Kinzo (1988), contudo, contesta especialmente a homogeneidade da aliança PTB-PSD. Sabe-se que boa parte dos componentes do PSD apoiou o Golpe de 1964 e a eleição indireta à Presidência da República do general Castelo Branco 9 mostrando que, posteriormente, grande parcela também optou por adentrar à Arena (78 deputados federais, enquanto 43 optaram pelo MDB).

Os primeiros anos de existência do MDB foram, assim, marcados por uma profunda falta de referenciais e definição tático-estratégica. Denunciando os excessos da ditadura e clamando pelo retorno à democracia ${ }^{10}$ no âmbito do Congresso, seu primeiro ensaio de atitude mais contundente de oposição se deu com a Frente Ampla. Esse movimento foi pautado na união de forças políticas conhecidamente adversárias, mas que se juntavam utilizando como denominador comum a luta pelo retorno à democracia: o ex-presidente João Goulart (exilado no Uruguai), o governador do Estado da

9 CPDOC-FGV. Veja. Partido Social Democrático (PSD1945-1965), 2009. Disponivel em: <http://bit.ly/33XNwyk>. Acesso em: 27 jul. 2018.

10 Democracia pautada, pelo partido, por um sistema representativo, de autonomia do Poder Legislativo, restabelecimento do habeas corpus, defesa dos direitos e das liberdades individuais, fortalecimento da autonomia regional, anistia a civis e militares, fim da política econômica recessiva e autonomia à organização sindical (KINZO, 1988, p. 63) 
Guanabara, Carlos Lacerda" e o ex-presidente Juscelino Kubitschek (exilado).

Iniciando a sua articulação em 1966, foi pautada em comícios e declarações públicas de repúdio às ações da ditadura. Representou importante momento de inflexão para o partido, uma vez que este realizou um flerte com uma atuação oposicionista mais contundente, ao invés de uma postura colaboracionista. Os anos finais da década de 1960 como um todo, especialmente o ano de 1968, viram uma resposta contundente da ditadura a essas movimentações. Isso esteve fortemente relacionado à emergência de um ciclo contestador da classe trabalhadora - ainda não visto desde 1964 -, especialmente nos âmbitos sindical e estudantil das metrópoles.

A reação se abateu com força inaudita. As ações da Frente Ampla foram proibidas em 1968 e a outorga do Ato Institucional $n .{ }^{\circ} 5$ a o final daquele ano (fechando o Congresso Nacional e facilitando as ações repressivas com a retirada de direitos humanos e políticos) se abateram pesadamente sobre a oposição como um todo. O MDB, particularmente, viu o seu âmbito de ação por excelência, o Congresso Nacional, fechado e a sua ação política totalmente constrangida.

Assim, podemos já ter uma impressão muito clara do que foi este MDB inicial. Com um caráter eminentemente frentista, agregando forças políticas contraditórias e amplas, foi mais um âmbito de organização da oposição à ditadura burgo-militar que criou, no poder institucional, freios ao governo e aos seus arbítrios do que um efetivo dirigente da oposição social ampla. Sofrendo com a descrença de setores da esquerda e a falta de intermediação com a classe trabalhadora (incipiente quando existia), restringiu-se ao âmbito e fazeres parlamentares. Tendo a sua ação mediada pela dialética oposição/repressão, o MDB se pautou pela cautela. Quando as suas críticas chegaram a um nível afrontoso

11 Após divergências com certas políticas da ditadura, Lacerda teria retirado o seu apoio formal ao regime e passado a apoiar as iniciativas da Frente após a confirmação da não realização das eleições presidenciais de 1965. demais para os militares ${ }^{12}$, a reação foi brutal e a cassação de quadros, gigantesca ${ }^{13} \mathrm{~A}$ reorganização institucional e redefinição estratégica seriam demoradas.

\section{Rearticulação: Encontrando - Caminho da Oposição}

A oposição à ditadura se cindiu ainda mais com a entrada no período de repressão mais intenso do regime militar. Ao longo dos primeiros anos da década de 1970 o País viu a emergência e o massacre das guerrilhas armadas urbanas e camponesas, bem como a caça aos elementos "subversivos" vistos pelo aparato repressor - coordenado pelo Serviço Nacional de Informações (SNI) - como ligados à "infiltração comunista". O governo do general Emílio Garrastazu Médici buscou esconder essa face sua da classe trabalhadora ao investir profundamente na propaganda ufanista e no progressismo tecnocrata, vangloriando-se do "milagre econômico" que levaria o Brasil para o futuro.

Para o MDB tal momento não poderia ser pior. Fortemente acossado pelo medo e terror de Estado que se abateu sobre seus membros, o partido viu uma renovação forçada de seus quadros (KINZO, 1988) enquanto mantinha uma política de cautela e conciliação (MOTTA, 1997) promovida pelo setor hegemonicamente "moderado" que sobreviveu à rodada de cassações. Nas eleições legislativas de 1970 os votos brancos e nulos conseguiram superar a votação emedebista (30\% do total de votos).

Em meados da década de 1970 esse quadro passou a mudar. Uma vez levemente arrefecidas as perseguições do período Médici, produziu-se um lento retomar do protesto político e do uso da rua como arena por excelência do

12 Conferir Alves (2005, p. 128-137). Ficou emblemático o caso do deputado federal Márcio Moreira Alves, cujo discurso inflamado no plenário acabou por iniciar um inquérito contra ele, promovido pelo governo e que gerou comoção suprapartidária na defesa de seu mandato.

13 Segundo Kinzo (1988, p. 118), o MDB perdeu cerca de $45 \%$ de seus parlamentares: 62 deputados federais, 4 senadores, 157 deputados estaduais, 293 vereadores e 12 prefeitos. 
conflito social. Como mostra Napolitano (2006), a morte de Vladimir Herzog causou tamanha comoção que as barreiras do medo foram levemente sobrepostas pela indignação contra a repressão. A classe trabalhadora passou a se reorganizar em luta e a reivindicar os seus direitos em um novo e longo ciclo contestador que foi de meados da década de 1970 até a de 1980, pautado principalmente pela luta sindical contra a política de arrocho salarial e perdas reais, contestação ao elevado custo de vida nas grandes cidades e mobilizações por reformas políticas de "liberalização" do regime e da retomada das "liberdades democráticas".

Toda essa série de mobilizações "de baixo" tiveram, claro, o seu impacto nas estruturas de poder. As eleições de 1974 foram essenciais para pensarmos o desenvolvimento do MDB, uma vez que atestaram que uma tática de contestação frontal ao regime (dentro dos limites por esse permitidos) traria resultados qualitativos exponenciais em termos de enraizamento social e identificação partidária. A "anticandidatura" de Ulysses Guimarães (presidente do partido) à Presidência da República foi essencial nesse intento. Ao atestar que não ganharia as eleições por estas serem um "jogo de cartas marcadas" no qual o candidato do governo, o diretor do SNI, general Ernesto Geisel, já teria a eleição garantida, mas ainda assim iria servir de figura pública do programa do MDB, Ulysses adotava uma postura de vigor oposicionista negada desde o início do partido ${ }^{14}$.

14 "O paradoxo é o signo da presente sucessão presidencial brasileira. Na situação, o anunciado como candidato, em verdade é o Presidente, não aguarda a eleição e sim a posse.

$\mathrm{Na}$ oposição também não há candidato, pois não pode haver candidato a lugar de antemão provido. [...] A inviabilidade da candidatura oposicionista testemunhará perante a Nação e perante o mundo que o sistema não é democrático, de vez que tanto quanto dure este, a atual situação sempre será governo. [...] Não é o candidato que vai percorrer o País. É o anticandidato, para denunciar a antieleição, imposta pela anticonstituição que homizia o AI-5, submete - Legislativo e o Judiciário ao Executivo, possibilita prisões desamparadas pelo habeas corpus e condenações sem defesa, profana a indevassabilidade dos lares e das empresas pela escuta clandestina, torna inaudiveis as vozes discordantes, porque ensurdece
A afluência de um novo grupo de emedebistas oposicionistas, os "autênticos" (NADER, 1997), auxiliou também em muito a renovação do partido e o tensionamento de seu programa em torno de teses liberais de teor democratizante que potencializaram seu apelo popular. A isso se associou uma profunda afluência de grupos de esquerda ao MDB, que lentamente ganhava um caráter de "oposição possível" mais forte já que as opções radicais tinham sido fisicamente eliminadas pelo governo ditatorial. Para esse partido a campanha contra o "não voto" era um dos grandes objetivos de seu posicionamento eleitoral, fazendo com que o apoio desses grupos de esquerda fosse ainda mais essencial.

Muito graças a essas influências advindas de novos militantes e do início da "crise do milagre" que avassalaria a economia brasileira na segunda metade da década de 1970 é que - MDB pôde politizar com mais intensidade a pauta econômica de seu programa. Assumindo para si um discurso nacionalista baseado na defesa da empresa nacional frente à entrada do capital estrangeiro em competição desleal, propiciada pelo governo, o partido criou para si o papel de defensor dos interesses nacionais e, por extensão, dos interesses do trabalhador. Ao adotar reivindicações caras ao movimento sindical em termos de revogação da política de arrocho salarial e defesa da organização sindical livre, o MDB pôde se conectar aos anseios de parte expressiva da classe trabalhadora, ocupando uma posição cada vez mais privilegiada nas organizações dessa classe.

Os resultados obtidos nas eleições legislativas de 1974 vieram corroborar o sucesso dessa rearticulação tática. Como mostra Kinzo (1988, p. 74), não só o MDB angariou 10 senadores a mais que a Arena naquelas eleições (16 a 6), conseguiu também quase que duplicar a sua representação na Câmara dos Deputados (foi de 87 a 160 representantes). $O$ bastião desses votos se provou a região Centro-Sul do País, notadamente os Estados de São Paulo, Rio de

a Nação pela censura à Imprensa, ao Rádio, à Televisão, ao Teatro e ao Cinema". (GUIMARÃES apud KINZO, 1988, p. 147) 
Janeiro e Rio Grande do Sul (61\% da votação nacional do partido). O eleitorado emedebista ganhou, então, uma face eminentemente urbana, operária/classe média e concentrado nas grandes capitais. Construtivamente, a Arena consolidou o seu bastião nas regiões Nordeste e Norte, onde a sua capilarização era facilitada pelo forte apoio infraestrutural e legislativo concedido pelo Governo Federal e às suas ramificações locais (ALVES, 2005, p. 191-192). Contando com forte apoio e ingerência da estrutura oficial de poder, o seu controle sobre as regiões de mais difícil acesso e mais empobrecidas do País foi tremendamente facilitado.

A reação militar não tardaria a se fazer presente. O governo Geisel começara a se fazer valer da figura enunciativa da "distensão" (MACIEL, 2014, p. 274), em um projeto de aparente diminuição das tensões entre governo e oposição para a abertura de um campo de diálogo onde o futuro do País pudesse ser construído mutuamente. Efetivamente, essa figura colocava o poder repressor e ingerente do Estado como igual ao da oposição (tanto formal quanto clandestinamente), em uma política que igualava e justificava as violências perpetradas pelo regime e abria caminho para uma resolução acordada dos conflitos que começavam a se instalar. O retorno do mentor teórico da doutrina de segurança nacional e desenvolvimento ${ }^{15}$ ao centro do poder, general Golbery do Couto e Silva, enquanto ministro-chefe do Gabinete Civil, viu o florescer da ideia de uma abertura "lenta, gradual e segura", na qual as Forças Armadas permitiriam a retomada do poder pelos civis desde que não houvesse uma "revanche" contra as casernas e os pilares da doutrina não fossem aviltados.

A Lei Falcão, que restringia o acesso aos meios de comunicação para a publicização das campanhas eleitorais e os pacotes de abril de 1977, que propunham uma conservadora reforma "liberalizante" do Judiciário, aprovados somente com o fechamento do Congresso, mostravam a quais níveis os militares esta-

15 Conferir Alves (2005, p. 33-51). vam dispostos a chegar para garantir que a sua visão particular do processo de abertura fosse concretizada. Em meio a esses ataques à oposição vemos o MDB reafirmando a sua posição enquanto partido, se não da ordem, dentro da ordem:

O MDB é um Partido provado e amadurecido no defrontar de situações semelhantes [às cassações de 1976], com as quais nunca se conformou. Jamais silenciará por temor ou acomodação: no Congresso, nas assembléias, Câmaras Municipais, nos órgãos de divulgação e nas campanhas, a voz dos seus representantes foi e será ouvida com a firmeza de sempre, repudiando qualquer forma de totalitarismo, protestando contra a violência e ilegalidade, rejeitando a insensatez e o radicalismo, conclamando à compreensão e à concórdia.

\section{$[\ldots]$}

Ao contrário do que muitos imaginam, o povo também pensa, analisa os fatos e aprende com as experiências; conscientiza bem os seus interesses e expressa o seu julgamento através do voto. O povo brasileiro, definitivamente, sabe que vale a pena e que é muito importante lutar através do voto. (GUIMARÃES, 1976, p. 139140, grifos nossos)

Reiteradamente reafirma que o seu local de atuação por excelência é o parlamento, e o voto é a sua arma de defesa da democracia. Isso mostra o quão irreal é demandar a ação radical do MDB, uma vez que não é um partido que se propõe a tal. Como coloca, o seu caminho é o da "compreensão e concórdia", elementos que serão essenciais para criar a retórica da conciliação, essencial para a chegada do MDB ao poder.

Dessa forma, não apenas o partido referenda o sistema em que atua ao não questionar radicalmente a ordem na qual se inscreve (fazendo apenas críticas de superfície), mas 
também referenda o programa de "distensão" e "abertura gradual" proposto pelo governo. Por isso é igualmente perigoso tomar esse período de rearticulação como uma guinada oposicionista radical ou subversiva à ordem. Foi meramente um reposicionamento "dentro das regras do jogo", no qual os espaços dados pelo governo tiveram os seus potenciais maximizados para fazer avançar o projeto político do partido e de seus líderes.

Isso mostra a dificuldade essencial de o MDB enfrentar o tema da representação política (KINZO, 1978; BORGES FILHO; MEZZAROBA, 2012). Especialmente se fizermos uma análise a partir de um paradigma materialista dialético, no qual a política não é o espaço do confronto das subjetividades, mas sim dos interesses de classe, o MDB sempre se dispôs (e o vemos desde os idos da Frente Ampla) a ser o partido da congregação das diferentes classes frente a um inimigo comum, visto no controle do poder de Estado pelas Forças Armadas.

Essa perspectiva ganhou fôlego no momento da abertura, que se tornou a transição democrática, à medida em que passou a representar para parte da classe trabalhadora uma real possibilidade de ter os seus interesses verdadeiramente defendidos pela oposição institucional. O MDB surgiu, assim, enquanto uma oposição viável. Contudo, houve forte esforço por parte do partido, beneficiado pela conjuntura de crise econômica, de se colocar frente à burguesia, em especial o empresariado, como uma opção aceitável de partido da ordem. Como define Maciel (2014), produz um campo de interlocução liberal no qual circularão não só empresários, mas também toda uma intelectualidade que compactue do ideal de gestão da ordem sob um ideal democrático de modernização do País e gestão tecnocrata do governo. Um dos grandes símbolos dessa intelectualidade foi Fernando Henrique Cardoso, que vemos ganhar cada vez mais proeminência nos debates programáticos internos do MDB, chegando a se tornar senador pelo partido (já enquanto PMDB), em 1983.

O novo ciclo contestador da classe trabalhadora mostrou a capacidade de o partido se conectar aos movimentos da conjuntura e se adaptar às demandas da oposição social. Quando, em uma estratégia de fragmentar a oposição, a ditadura extingue o MDB e a Arena e afrouxa a legislação para a criação de novos partidos, a recomposição do grupo político que formou o PMDB assim se posicionou:

Enquanto o governo preserva o controle sobre o aparelho do Estado através de expedientes que esvaziam de conteúdo real as instituições republicanas, tornando-as verdadeira farsa para deturpar a vontade popular, procura, ainda que de maneira confusa e vacilante, assegurar um crescimento econômico, afastando as maiorias populares da riqueza e do poder. [...] Exige que as formas limitadas do pluralismo político tolerado se desenvolvam dentro dos estreitos, porém variáveis limites impostos pelos governantes para que a maioria não se torne militante e mobilizada. Nesse sentido procura reduzir os cidadãos a uma massa inerme e obediente, [...] para impedir que a luta da oposição, dentro ou fora dos partidos, frustre essas intenções liberticidas. (BANCADA DO PMDB, 1981, p. 11, grifos nossos)

De um horizonte, em 1976, no qual as assembleias e o voto eram compreendidos como as principais ferramentas de luta da oposição, chega-se a 1981, onde a "vontade popular" é expressa tanto dentro quanto fora dos partidos. Vemos claramente o PMDB buscando agregar para si não só os espólios dessa intensa mobilização popular, mas também ocupar a posição de coordenação desse amplo movimento de insatisfação para com o governo. A questão da desigualdade, miséria e justiça social passaram cada vez a serem mais frequentes nos discursos dos pemedebistas, buscando justamente alimentar as insatisfações de seu eleitorado cativo dos grandes centros urbanos.

Vemos, portanto, o PMDB tentar entrar em consonância com o que Marcos Napolitano (2006) define como "nova cultura política" no Brasil, relacionada a esse momento de reconquista das ruas pelas organizações da sociedade civil, porém, pautadas por paradigmas 
diferentes daqueles da década de 1960. O "novo sindicalismo" surgido nas greves do ABC passou a questionar a estrutura sindical compreendida como "pelega" e a requisitar organizações autônomas e desatreladas da estrutura oficial, contrastando tanto com o governo ditatorial, quanto aos sindicatos de herança varguista. $O$ movimento do custo de vida atestava a crescente urbanização desenfreada e a pauperização da vida nas periferias das grandes cidades, particularmente em São Paulo. Os saques que abalaram a capital paulista em 1983 mostravam a extensão a que chegava o descontentamento social. O movimento estudantil se rearticulava em torno da retomada da União Nacional dos Estudantes. Organizações como a Ordem dos Advogados do Brasil passaram a colocar em discussão a convocação de uma assembleia constituinte que reformasse/substituísse a Constituição de 1967 (reformada em 1969).

Reinhart Koselleck (2006) nos auxilia a compreender esse momento se valendo dos conceitos de campo de experiência e horizonte de expectativa. $O$ historiador alemão define o primeiro como o conjunto das experiências coletivamente sentidas por um grupo social, moldando a sua visão de mundo e compreensão sobre o seu passado, compreensão esta que é orgânica e está em constante mudança, conforme as novas camadas de experiência se adicionam a esse campo. Já o horizonte de expectativa é um resultado direto do campo, uma vez que reúne o rol de esperanças e anseios de futuro produzidos por aquele grupo social baseado em suas experiências, na sua percepção de passado, em sua memória.

Podemos pensar que a transição democrática no Brasil angariou às diferentes organizações da classe trabalhadora um campo de experiência que tensionou em muito o projeto de distensão e abertura planejado pelo governo ditatorial. Na prática cotidiana da luta por seus direitos, essas organizações reescreveram a sua história e contestaram o senso comum de que a História do Brasil se deu sem contestações por parte dos "de baixo". Isso levou à produção de um novo horizonte de expectativa, amplo, ambíguo e fora dos ditames de uma abertura "sem povo". A radicalização dos protestos de rua e dos projetos de país que se gestavam nos mesmos causou um elevado medo por parte da ditadura e se tornou o grande desafio para todas as agremiações oposicionistas, obrigadas a se conectar a essas mobilizações para não perderem a sua relevância na transição. A campanha pelas eleições diretas foi essencial no processo de conquista da coordenação da oposição à ditadura pelo PMDB.

\section{Chegada ao Poder de Estado}

Ao longo do governo do general Baptista Figueiredo vemos a concretização do processo de crise da ditadura e deslegitimação. Com a reforma partidária ${ }^{16}$ de 1979 vemos o surgimento de novos partidos no cenário político institucional. Contudo, o PMDB não perdeu o seu vigor, mantendo, nas eleições de $1982^{17}$, o caráter de agremiação hegemônica da oposicão institucional. Ainda que manifestações da extrema-direita tenham tensionado o debate político e instaurado um pontual clima de medo contra a retomada das ruas pela classe trabalhadora, não puderam conter a sua ascensão. O ápice desse processo foi a campanha pelas eleições diretas, entre 1983 e 1985, que abalou

16 Além da rearticulação dos velhos partidos da ditadura (Arena se tornou o PDS, MDB se tornou o PMDB), viu-se o surgimento de novos partidos, tais como $\circ$ Partido Democrático Trabalhista (comandado por Leonel Brizola), o ressurgimento do Partido Trabalhista Brasileiro (retomado por Alzira Vargas), o Partido dos Trabalhadores (cuja principal figura era o líder sindicalista Luís Inácio Lula da Silva) e o fugaz Partido Popular (organizado por Tancredo Neves, que foi incorporado ao PMDB em 1981).

17 Ainda que tenha sido uma eleição já sob pleno clima de abertura, houve um intenso esforço por parte do governo de tensionar os resultados em favor do PDS: existência de senadores biônicos (eleitos por um colégio eleitoral em 1978), voto vinculado (em que todos os cargos deviam ser da mesma sigla, ações clandestinas de intimidação da oposição. Ainda assim o PMDB conquistou 200 vagas na Câmara dos Deputados (contra 235 do PDS), 21 senadores (contra 46 do PDS) e 9 governadores (contra 12 do PDS). PDT, PTB e PT tiveram ganhos também, porém, em um patamar bastante inferior (ALVES, 2005, p. 285). 
as estruturas do poder e mostrou a amplitude a que chegou o movimento oposicionista.

Ainda que possam ter sido iniciadas por intermédio do PT (NAPOLITANO, 2006), as Diretas Já! foram rapidamente capturadas pelo PMDB. O caráter frentista do partido se alinhou muito bem à ambivalência do movimento, que angariava vários grupos diferentes, cada qual com o seu projeto político específico. Kinzo (1993) defende que a amplitude e ambiguidade da doutrina partidária pemedebista assumiu um caráter estratégico em sua ação política, uma vez que, ainda que causasse repulsa por parte de grupos mais politicamente definidos, angariava um apoio abrangente e de massas, tanto entre grupos organizados como os não organizados da população. A campanha pelas Diretas deixou bem claro esse teor agregador do partido, já que conseguia criar um campo comum entre a oposição na defesa de uma indefinida democracia, que poderia ser aquilo que o indivíduo compreendesse como tal.

Ao passo que figuras como Ulysses Guimarães, Franco Montoro e Mário Covas buscavam se aliar fortemente ao movimento, passando a participar ativamente das manifestações e assumindo caráter de lideranças dessas, outra ala do PMDB buscava garantir um cenário benéfico ao partido com o governo. A ala mais conservadora do partido, da qual Tancredo $\mathrm{Ne}$ ves era um dos dirigentes, manteve um campo ativo de negociações com o governo, garantindo-o que o PMDB não tensionaria o debate político para além dos ditames da abertura lenta e gradual (MACIEL, 2014). Estava em curso o horizonte da "conciliação", através do qual - partido ganhou proeminência no constante processo de parlamentarização do conflito social no País.

Como defendido, o PMDB era um partido dentro da ordem colocada, o que sempre constrangia o seu discurso e a sua ação. A isto sempre se adicionava o constante terror de Estado e as ameaças que ciclicamente se abatiam sobre o partido. Assim, ao longo da transição ocupou um papel essencial para os ditames do projeto ditatorial de abertura, já que atrelava sempre a ação oposicionista ao âmbito parlamentar. Ainda que, como visto, o seu discurso passou a agregar as diferentes mobilizações de rua da classe trabalhadora, estas eram sempre utilizadas pelo partido para legitimar a sua ação oposicionista. Igualmente ao PMDB não interessavam contestações mais estruturais e radicais à ordem socioeconômica (que fossem além do vago discurso de combate à miséria e desigualdade social), já que se dispunha a ser governo e reformar o Estado controlado pelas Forças Armadas - e não o derrubar. Essa estratégia se dava por razões bastante concretas: as frações mais contestadoras do partido foram cassadas ou exiladas, os grupos vistos como "moderados" eram constantemente ameaçados pelo governo a terem cautela em seus questionamentos, de modo que o partido precisaria do apoio das frações burguesas se quisesse chegar ao poder sem mudar a ordem, entre outras tantas motivações.

O processo de parlamentarização estaria, portanto, na dialética de apoio às mobilizações de massa que criticavam a ditadura, ao passo que se buscava consubstanciar o descontentamento social, o debate político e a luta de classes no âmbito parlamentar. No Congresso Nacional poderiam ser controlados e terem a sua potência contestatória minorada, de forma a manter a tessitura do sistema político-econômico.

Isso se tornou claro no momento de rejeição da Emenda Dante de Oliveira, que concederia a realização de eleições diretas à Presidência da República, e provocou uma rápida mobilização do PMDB no sentido de preparar o seu candidato à eleição indireta em 1985, Tancredo Neves. A criação de uma campanha que contou com apoio popular viu justamente esse intuito de transferir o forte apoio popular às diretas em um apoio à eleição de Tancredo. O PMDB realizou uma operação de ressignificar o Colégio Eleitoral que elegeria o próximo presidente, espelhando na eleição de Tancredo uma vitória popular sobre a ditadura ${ }^{18}$.

18 Com grande apoio da mídia, diga-se de passagem, especialmente no campo semiótico. Ficou emblemática a capa da Revista Veja de 23 de janeiro de 1985, 
O amplo apoio angariado pela população foi claro, porém, foi o Congresso Nacional o grande âmbito de disputa das eleições de 1985. Conquistando o apoio de uma série de partidos oposicionistas e organizações de esquerda (à exceção do PT), a grande articulação que possibilitou a chegada do PMDB ao governo foi a Aliança Democrática. Com a escolha dos deputados federais Paulo Maluf e Flávio Marcílio como candidatos a presidente e vice do partido da ditadura (PDS), uma série de descontentes passou a intensificar as negociações com o PMDB, que levaria à criação da Frente Liberal, capitaneada por José Sarney (ex-presidente do PDS) e contando com Marco Maciel (ex-governador de Pernambuco), Aureliano Chaves (vice-presidente de João Figueiredo) e Mário Andreazza (ministro do interior de João Figueiredo).

A dissidência do PDS findou os horizontes de vitória do partido do governo e selou a chegada do PMDB ao poder. Com a vitória da chapa Tancredo Neves e José Sarney no Colégio Eleitoral, em 15 de janeiro de 1985, um novo horizonte de expectativa se produzia, tanto para o PMDB, quanto para o Brasil. O desafio de montar uma oposição possivel e uma opção de governo viável havia sido transposto, e uma série de novos se abriam.

\section{Considerações Finais}

Torna-se importante frisar o papel a longo prazo assumido pelo P/MDB na política brasileira no período destacado. Vemos que ao longo das décadas de 1960 e 1970 buscou para si o local a ocupar dentro da oposição à ditadura burgo-militar instaurada no Brasil em 1964. Contudo, foi apenas a partir de 1974 que conseguiu ultrapassar a função institucional para a qual foi criado, dentro do planejamento da ditadura, de referendar o sistema do qual participava. Essa demora em definir um rumo a seguir se deu justamente pela dialética entre ação oposicionista e repressão estatal, que

quando esta fez uma transposição entre o rosto de Tancredo Neves e a bandeira brasileira com a chamada TANCREDO PRESIDENTE: o doce dia da caça. pautou todo o desenvolvimento pemedebista nessa primeira etapa.

Os ensaios de uma ação mais incisiva foram sempre barrados pelos movimentos de reação arbitrária estatal e uso da força. Isso acabou moldando a tática do partido de forma a sempre evitar contestar o regime em suas estruturas básicas, adotando um discurso de reforma liberal com preocupação social que pautou a sua compreensão de horizonte de expectativa democrático. O grupo dos "autênticos", de formação política já realizada no contexto da ditadura, foi essencial no encanamento dessas teses, vistas como um passo mais incisivo que a perspectiva colaboracionista dos "moderados".

Contudo, esse ideário reformista acabou ganhando um caráter cada vez mais conservador conforme a transição se avizinhou. Apesar de conseguir adequar o seu discurso para incorporar as diversas organizações da classe trabalhadora e as novas pautas que levantavam em seus protestos de rua, o PMDB as instrumentalizou para servirem à sua chegada ao poder. Atuando em duas frentes, buscou ganhar tanto na população a prerrogativa de oposição oficial e por excelência à ditadura, quanto no empresariado e na burguesia brasileira a confiança enquanto uma opção viável de governo. Isso foi condensado na retórica da "conciliação", capitaneada por Tancredo Neves, a partir da qual a perspectiva "segura" da abertura prevista pelo general Golbery seria a pedra de toque da ação oposicionista, de forma a garantir um governo do PMDB que possuísse o mais amplo possivel apoio popular e institucional.

Ainda que a sua indefinição programática para além da requisição de retorno à democracia fosse um grande empecilho para definição tática e estratégica, revelou-se, com uma conjuntura favorável, bastante positiva no sentido de reforçar o caráter frentista do partido e seu poder de agregar as diferentes oposições ao governo ditatorial. Os diferentes contextos de terror de Estado e constrição da ação oposicionista angariaram ao P/MDB uma necessária adaptabilidade e maleabilidade, conseguindo fazer do seu discurso aquilo que 
a conjuntura demandasse dele. Justamente essa adaptabilidade que permitiu a formação da Aliança Democrática e a vitória da chapa pemedebista no Colégio Eleitoral, em 1985.

A aliança entre Tancredo Neves e José Sarney, bem como o amplo apoio de vários setores descontentes com a ditadura mostram um elevado grau de amadurecimento do partido e de domínio do funcionamento do sistema político no qual estava inscrito. Esse crescimento dentro do sistema levou à sua chegada ao poder, mas ao longo do governo de José Sarney e da década de 1980 se mostraria também um grande fator de desestabilização, à medida que a variedade de grupos e interesses dentro do partido começavam a se tornar cada vez mais irreconciliáveis, especialmente com o agravamento da crise econômica e as demandas por um programa político que fosse além do discurso ambíguo e agregador do PMDB (ainda mais no período da Assembleia Nacional Constituinte de 1987-1988). O partido da conciliacão teve cada vez mais dificuldade em conciliar os seus interesses internos.

\section{Referências Bibliográficas}

ALVES, M. H. M. Estado e oposição no Brasil (19641984). Bauru, SP: Edusc, 2005.

ANGELI, D. S. O Movimento Democrático Brasileiro (MDB) e a defesa da Constituinte como caminho para a democracia. In: SEMINÁRIO DE ESTUDOS HISTÓRICOS, 11., 2012. Disponível em: <https://www.feevale.br/Comum/ midias/014aba56-e511-40ac-bb14-8744c9839d72/O\%2OMOVIMENTO\%2ODEMOCR\%C3\%81TICO\%2OBRASILEIRO\%2O(MDB)\%20 E\%20A\%20D.pdf>. Acesso em: 5 jul. 2018.

AQUINO, M. A. de. Censura, imprensa e Estado autoritário (1968-1978): o exército cotidiano da dominação e da resistência (O Estado de São Paulo e Movimento). Bauru, SP: Edusc, 1999.

ARRUDA, P. Partidos políticos e disputa eleitoral no Brasil. São Paulo: Educ, 2016.

BAKHTIN, M. Os gêneros do discurso. São Paulo: 34, 2016.
BANCADA DO PMDB. Manifesto dos fundadores do PMDB à nação. Revista do PMDB, Rio de Janeiro, v. 1, n. 1, 1981.

BORGES FILHO, N.; MEZZAROBA, O. O partido político em Marx, Engels e Gramsci. Revista Técnica, jun. 2012. Disponível em: <https://www. tre-sc.jus.br/site/resenha-eleitoral/revista-tecnica/edicoes-impressas/integra/2012/06/o- partido-politico-em-marx-engels-e-gr>. Acesso em: 7 abr. 2019.

BRASIL. Senado Federal. 1974 - a eleição que abalou a ditadura. Jornal do Senado, Brasília, DF, 19 nov. 2014. Disponível em: <https://www12.senado.leg.br/jornal/edicoes/especiais/2014/11/19/ jornal.pdf>. Acesso em: 26 ago. 2018.

CAMPOS, E. del; RAMOS, M. L. La paradoja partidista: institucionalización y representación em los partidos políticos latinoamericanos. América Latina Hoy, Salamanca, España, n. 16, p. 29-39, ago. 1997.

CARVALHO, A. Democracia e desenvolvimento versus segurança e desenvolvimento: as eleições de 1974 e a construção de uma ação oposicionista pelo MDB na década de 1970. Varia História, Belo Horizonte, MG, v. 28, n. 48, p. 555-572, jul./dez. 2012.

CARVALHO, G. A. B. Democracia e representação: territórios em disputa. Teoria e Pesquisa, Brasília, DF, v. 1, n. 25, p. 250-256, 2016.

CHASIN, J. A miséria brasileira: 1964-1994 - do golpe militar à crise social. Santo André, SP: Edições Ad Hominem, 2000.

CHOULIARAKI, L.; FAIRCLOUGH, N. Discourse in late modernity. Edinburg, RU: Edinburg University, 2007.

COGGIOLA, O. O ciclo militar na América do Sul. Blog da Boitempo, 2014. Disponível em: <https:// blogdaboitempo.com.br/2014/03/24/o-ciclo-militar-na-america-do-sul>. Acesso em: 26 maio 2018. COLOMBO, L.; SOARES, A. O.; TAUIL, R. M. O bipartidarismo no Brasil e a trajetória do MDB. Sinais, Vitória, ES, n. 19, p. 7-29, jan./jun. 2016.

COUTO, R. C. Memória viva do regime militar Brasil: 1964-1985. Rio de Janeiro: Record, 1999. 
CORRÊA, A. E. A Frente Liberal e a democracia no Brasil. São Paulo: Nobel, 2006.

COSTA, C.; GAGLIARDI, J. Lysâneas, um autêntico do MDB. Estudos Históricos, Rio de Janeiro, n. 37, p. 201-212, jan./jun. 2006.

DIRETÓRIO NACIONAL DO MOVIMENTO DEMOCRÁTICO BRASILEIRO. Constituinte com anistia - compromissos políticos, sociais e econômicos do MDB. Brasília, DF, 1978.

MDB em ação. v. 14. Brasília, DF: Senado

Federal, Centro Gráfico, 1986.

MDB em ação. v. 11. Brasília, DF: Senado Federal, Centro Gráfico, 1976.

MDB em ação. v. 10. Brasília, DF: Senado Federal, Centro Gráfico, 1972.

DREIFUSS, R. A. 1964: a conquista do Estado ação política, poder e golpe de classe. Petrópolis, RJ: Vozes, 2008.

DUPAS, G. Crise econômica e transição democrática: 83/86 - a delicada trajetória brasileira. São Paulo: Klaxon, 1987.

DUVERGER, M. Os partidos políticos. Rio de Janeiro: Zahar, 1970.

EULAU, H.; KARPS, P.D. The puzzle of representation: specifying components of responsiveness. Legislative Studies Quarterly, Hoboken, NJ, USA, v. 2, n. 3, p. 233-254, aug. 1977.

FAIRCLOUGH, N. Análise crítica de discurso como método em pesquisa social científica. Trad. Iran Ferreira de Melo. Língua d'Água, São Paulo, v. 2, n. 25, p. 307-329, 2012.

FAORO, R. Assembleia Constituinte: a legitimidade recuperada. São Paulo: Brasiliense, 1981.

FIGUEIREDO, C. A. S. A relação dos PC'S com o MDB-PMDB no cenário da transição e as eleições de 1982 no RS. 2009. 145 f. Dissertação (Mestrado em Ciências Políticas) - Instituto de Filosofia e Ciências Humanas da Universidade Federal do Rio Grande do Sul, Porto Alegre, RS, 2009.

FORGET, D. Conquistas e resistências do poder. São Paulo: Edusp, 1994.

FUNDAÇÃO Pedroso Horta, 1981-1989. Revista do PMDB, Rio de Janeiro, [19--?].
FUNDAÇÃO ULYSSES GUIMARÃES. 50 anos: PMDB. O partido que muda o Brasil. Brasília, DF: Positiva, 2016.

GARCIA, M. A. (Org.). As esquerdas e a democracia. Rio de Janeiro: Paz e Terra; Cedec, 1986.

GUIMARÃES, U. MDB em ação. v. 10. Brasília, DF: Senado Federal; Centro Gráfico, 1976.

INSTITUTO DE ESTUDOS POLÍTICOS “PEDROSO HORTA"; MOVIMENTO DEMOCRÁTICO BRASILEIRO. A luta pela democracia - MDB no rádio e televisão. Brasília, DF: Senado Federal, Centro Gráfico, 1977.

JURUCÊ, R. O partido político para Antônio Gramsci: o papel histórico dos intelectuais e dos aparelhos de hegemonia. PCB, [20--]. Disponivel em: <https://pcb.org.br/portal/precongresso/ juruce.pdf>. Acesso em: 26 ago. 2019.

KINZO, M. D'A. G. Radiografia do quadro partidário brasileiro. São Paulo: Konrad-Adenauer-Stiftung; Centro de Estudos, 1993.

Oposição e autoritarismo: gênese e trajetória do MDB. São Paulo: Vértice; Revista dos Tribunais, 1988.

Representação política: perspectivas teóricas e um exame da experiência brasileira. 1978. 149 f. Dissertação (Mestrado em Ciência Política) - Faculdade de Ciências Sociais da Pontifícia Universidade Católica de São Paulo, São Paulo, 1978.

O legado oposicionista do MDB: o Partido do Movimento Democrático Brasileiro. Anpocs, [20--]. Disponível em: <https://www.anpocs.com/ index.php/encontros/papers/17-encontro-anual-da-anpocs-1/st-2/st07-2/7323-mariakinzo-legado/file>. Acesso em: 5 jul. 2018.

KOSELLECK, R. Futuro passado. Rio de Janeiro: Contraponto; PUC-Rio, 2006.

LÊNIN, V. Duas táticas da social-democracia na revolução democrática. Marxists, 2007. Disponível em: <https://www.marxists.org/portugues/lenin/1905/ taticas/index.htm>. Acesso em: 26 ago. 2019.

MACIEL, D. A argamassa da ordem: da Ditadura Militar à Nova República (1974-1985). São Paulo: Xamã, 2004. 
MACIEL, N. R. A. Velhas raposas, novos governistas: o PMDB e a democracia brasileira. 2014. $225 \mathrm{f}$. Tese (Doutorado em Ciência Política) - Instituto de Estudos Sociais e Políticos da Universidade do Estado do Rio de Janeiro, Rio de Janeiro, 2014.

MADEIRA, R. M. Dinâmica eleitoral e partidária em um contexto ditatorial: a relação entre elites políticas e o regime. Research Gate, 2016. Disponivel em: <https://www.researchgate. net/publication/312134387_Dinamica_eleitoral_e_partidaria_em_um_contexto_ditatorial_a_relacao_entre_elites_politicas_e_o_regime_1965-1979>. Acesso em: 26 ago. 2019.

MARTINS, L. Ação política e governabilidade na transição brasileira. In: MOISÉS, J. Á.; ALBUQUERQUE, J. A. G. (Org.). Dilemas da consolidação da democracia. Rio de Janeiro: Paz e Terra, 1989.

MARTINS, L. B.; NEVES, G. R.; SILVA, E. da (Org.). Tancredo Neves - pensamentos e fatos. Brasília, DF: Fundação Ulysses Guimarães, 2013.

MENDES, R. A. S. Ditaduras civil-militares no Cone Sul e a Doutrina de Segurança Nacional - algumas considerações sobre a historiografia. Tempo e Argumento, Florianópolis, SC, v. 5, n. 10, p. 6-38, jul./dez. 2013.

MENDONÇA, D. de. A vitória de Tancredo Neves no Colégio Eleitoral e a posição política dos semanários Veja e Isto É. Revista Alceu, v. 5, n. 10, jan./jun. 2005.

MENEGUELLO, R. Partidos e governos no Brasil Contemporâneo (1985-1997). São Paulo: Paz e Terra, 1998.

MOTTA, R. P. S. Cultura política e ditadura: um debate teórico e historiográfico. Tempo e Argumento, Florianópolis, SC, v. 10, n. 23, p. 109137, jan./mar. 2018.

Partido e sociedade - a trajetória do MDB. Ouro Preto, MG: Ufop, 1997.

MUCINHATO, R. M. D. Um passo adiante, dois passos para trás: o PMDB de 1979 a 1982. 2015. 164 f. Dissertação (Mestrado em Ciência Política) Faculdade de Filosofia, Letras e Ciências Humanas da Universidade de São Paulo, São Paulo, 2015.
O processo de fundação do PMDB (19791980). Conferências FFLCH, 2014. Disponível em: <http://conferencias.fflch.usp.br/sdpscp/IVsem/ paper/download/129/86>. Acesso em: 26 ago. 2019.

NADER, A. B. Juntando os fragmentos do discurso político nacional: história oral de vida do grupo "Autênticos do MDB". 1997. 660 f. Tese (Doutorado em Educação) - Faculdade de Educação da Universidade Estadual de Campinas. Campinas, SP, 1997.

NAPOLITANO, M. Cultura e poder no Brasil Contemporâneo. Curitiba, PR: Juruá, 2002.

PÁDUA, G. D. O herói conciliador: a construção da imagem de Tancredo Neves nas revistas Veja e Manchete (1982-1985). 2011. 269 f. Dissertação (Mestrado em Comunicação e Semiótica) Pontifícia Universidade Católica de São Paulo, São Paulo, 2011.

PAIVA, C. G. Uma viagem pelo discurso parlamentar: gênero discursivo por desvendar. 2006. 122 f. Dissertação (Mestrado em Linguística) Instituto de Letras da Universidade de Brasília, Brasília, DF, 2006.

PARTIDO DO MOVIMENTO DEMOCRÁTICO BRASILEIRO. Programa - Estatuto - Código de Ética. São Paulo: [19--?].

PÊCHEUX, M. O discurso: estrutura ou acontecimento. Campinas, SP: Pontes, 2006.

Hacia el análisis automático del discurso. Madrid: Biblioteca Románica Hispánica; Editorial Gredos, 1978.

PINHEIRO, M. (Org.). Ditadura: o que resta da transição. São Paulo: Boitempo, 2014.

RAMALHO, V.; RESENDE, V. de M. Análise de discurso (para a) crítica: o texto como material de pesquisa. Campinas, SP: Pontes, 2011.

REVISTA Veja, São Paulo, [números selecionados], 1974, 1978-1979, 1982, 1984, 1986-1987, 1989.

SAES, D. República do capital - capitalismo e processo político no Brasil. São Paulo: Boitempo, 2001.

SANTAYANA, M. Conciliação e transição: as armas de Tancredo. Rio de Janeiro: Paz e Terra, 1985 